\title{
sciendo
}

DOI 10.2478/sbe-2020-0042

SBE no. 15(3) 2020

\section{DIFFERENCES IN EXCHANGE RATE EFFECTS ON PRODUCTION GROWTH: THE CASE OF IRANIAN INDUSTRIES}

\author{
EBRAHIMI SAJAD \\ Monetary and Banking Research Institute, Iran
}

GHADERI OMID

M.A. graduate in economics, Iran

BAYAT SAEED

Central Bank of Iran, Iran

\begin{abstract}
:
There has been a long debate about whether exchange rate depreciation promotes output growth or not. In this context, we use Iran's foreign exchange market which has had large fluctuations in recent years. Since the exchange rate influence on industries' activity through different mechanisms, we examine the exchange rate effects in the industry level. To do this, the Iranian manufacturing industries data at 4-digit ISIC level are used from 2011 to 2017. The results of GMM dynamic panel data estimations show that the effects of real exchange rate depreciation on average, are positive in the non-crisis periods. But this relationship does not remain valid in a currency crisis conditions. Accordingly, depreciation does not have any positive effects during the currency crisis. Also, estimation results indicate the exchange rate volatility negatively affects industrial production in all periods. Our findings confirm that due to different characteristics of industries, the effects of exchange rate on production vary among them. So, export orientation, access to the preferential rate and higher level of raw material inventory amplify the positive effect of the real depreciation while import dependency and a higher level of final goods inventory fade the effect and turn into negative in some industries.
\end{abstract}

Key words: Exchange Rate, Volatility, Production, Export Oriented, import dependency

\section{Introduction}

Large depreciation of Iran's national currency in 2012 has dramatically affected the output and economic growth especially in sectors which have a strong connection with foreign markets. Occurring a large exchange rate depreciation provides a potential source to identify the effects of exchange rate fluctuations on production growth in a developing country. Many studies have debated the role of exchange rate shocks in the real sector. One of the first analyses about the impact of exchange rate devaluation on output and 
employment is found in the work of Hirschman (1949), who showed that a devaluation, starting from an initial trade deficit, may lead to a fall in real income as long as the increase in spending on importable goods and services exceeds export receipts (Agenor, 1991).

Generally, related studies can be divided into two parts. Some studies such as Guitian (1976), Dornbusch (1988), and Dornbusch et al. (1994) have emphasized the traditional view that exchange rate devaluation has an expansionary effect on the demand side and its appreciation results in restraining the output growth. On the other hand, a considerable literature showed that exchange rate devaluations have contractionary effect on output growth through different mechanisms. Krugman and Taylor (1978) theoretically explain that and Cooper (1971), Kamin (1988), and Edwards (1989) empirically examine the negative effect, also Van Wijnbergen (1986), and Bruno (1979) show the adverse effects of exchange rate depreciation on the supply side. However, besides the overall effects of exchange rate movements, some studies (Dhasmana (2015) and Eichengreen (2007)) show that the effect of exchange rate varies across different sectors. In this paper, we examine the difference in the effects of exchange rate on output growth across industries.

Initial theoretical interpretation is that exchange rate can affect the profit margin of industries through two channels; influencing on the price of imported inputs and the price of exported products. Direction and magnitude of these effects depend on the strength of each of these channels. Therefore, exchange rate movements, through the profit margin channel, can increase output of some industries and decrease some others. Given different effective mechanisms of exchange rate on industrial sectors' activities, the paper aimed to investigate the strength and direction of exchange rate effects across manufacturing industries. Also, we empirically examine the role of industries characteristics like labor intensity, levels of raw material and final products inventory, market concentration, type of ownership, accessing to foreign currencies with preferential rate as well as the degree of export orientation and import dependency in the relationship between the exchange rate growth and output growth in different Iranian industries during the large depreciation period.

For this, we use quarterly data of 96 manufacturing industries at 4-digit ISIC level from 2011 to 2017 . The hypothesis is that the direction and intensity of exchange rate changes effectiveness on production of each industry are different from other ones, and these differences are related to some characteristics of industries. For example, we examine whether labor intensity, state ownership, and degree of export orientation reinforce the positive effect of exchange rate on production in different industries. Furthermore, we test whether lower levels of raw material inventory, the degree of import dependency, and degree of market competitiveness strengthen the negative effects of exchange rate on production. Moreover, since Iranian economy engaged in currency crisis in 2011 and 2012, the effect of exchange rate on industries' output growth is examined separately in the currency crisis period and after that. In other words, we test whether the effect of exchange rate during the currency crisis is different from other periods.

The remainder of the paper proceeds as follows: section 2 discusses theoretical foundations. Section 3 contains the literature review. Section 4 describes the dataset used in the research and explains the research methodology and lays out the panel data model, 
Section 5 reports estimation results and discusses their interpretations, and the last section concludes.

\section{Theoretical Foundations}

In the literature, exchange rate, as a relative price, affects economic growth (Krueger, 1998). Japan, Singapore, and China's experiences are empirical evidence for such relations. The exchange rate policy and manipulating this relative price in tradable markets have boosted the production of exporter sectors in those countries, where increase of economic growth is a consequence of these policies.

In a simple model of profit maximization at the firm level, we can structurally show the effects of exchange rate on production. For simplicity, without loss of generality, we assume the representative firm is price taker and its production is equal to its selling (no output inventory). So, the profit of the firm in a specific time period is as follows:

$$
\begin{aligned}
& \pi=P_{d} Q_{d}\left(x_{d}, x_{f}\right)+P_{f} Q_{f}\left(x_{d}, x_{f}\right)-w_{d} x_{d}-w_{f} x_{f} \\
& Q=Q_{d}+Q_{f} \\
& P_{f}=e P^{f} \\
& w_{f}=e w^{f}
\end{aligned}
$$

Where $\pi$ is profit function, $P_{d}$ is the price of product in the domestic market, $Q_{d}$ govern the amount of product sold in the domestic market, $P_{f}$ is the price of product in the foreign market (in terms of the national currency), $Q_{f}$ represents the amount of product sold in the foreign market, $x_{d}$ and $x_{f}$ are respectively internal production input and production input bought from abroad, $w_{d}$ and $w_{f}$ represent respectively the price of internal production input and the price of production input bought from abroad (in terms of the national currency). Also, $Q$ is the total production (sold in the domestic and foreign markets), ${ }^{e}$ governs the exchange rate (the price of foreign currency in terms of the national currency), $P^{f}$ and $w_{f}$ are the price of foreign product and foreign input in terms of foreign currency.

Maximizing profit, the demand function of the internal production input and production input bought from abroad are obtained:

$$
\begin{aligned}
& x_{d}=x_{d}\left(P_{d s} P^{f}, \varepsilon_{s} w_{d s} w^{f f}\right) \\
& x_{f}=x_{f}\left(P_{d}, P^{f}{ }_{s} e_{s} w_{d s} w^{f}\right)
\end{aligned}
$$

Replacing the demand functions in the total production, it can be seen that exchange rate movements affect the total production:

$$
Q\left(x_{d}, x_{f}\right)=Q_{d}\left(x_{d,} x_{f}\right)+Q_{f}\left(x_{d}, x_{f}\right)=Q\left(P_{d,} P^{f}, \theta_{w}, w_{d}, w^{f}\right)
$$

Equation (7) indicates the optimal level of production depends on domestic and

$$
w_{d e} w^{f}
$$$$
P_{\text {de }}, P^{f}
$$

foreign prices of inputs ( ) and product ( ). Also, exchange rate affects the optimal level of production. The effect of exchange rate on the production occurs through two channels. First, the exchange rate movement changes the price of imported input (in terms of the domestic currency). Second, the price of exported product depends on 
exchange rate. Since these channels have opposite effects, the direction of total effect of exchange rate is ambiguous and depends on the strength of the channels. If those two main assumptions of the model (price taking and the equality of production and sales) are put away, price setting behavior of industries and the product inventory (the difference between production and sale) will be important in the relation between exchange rate and production.

Therefore, according to the simple model, industry properties like ownership structure and access to foreign currencies with preferential rate which have impact on price setting behavior, as well as export orientation (percentage of products sold in foreign markets), import dependency (percentage of input imported from foreign markets) and inventory level can influence the relationship between exchange rate and production in different industries. Note that we only modeled the effects of exchange rate movement, however, exchange rate volatility has significant effect on production and employment. Uncertainties resulted from exchange rate volatilities reduce incentives for investing in different industry sectors, and so decrease the production in the industries.

\section{Literature Review}

Exchange rate affects output through the trade channel. Exchange rate movement induces real changes in import and export of commodities, therefore, production in various industries is differently influenced by these changes. In this context, export-led growth literature introduced by Kindleberger (1962) and developed by other studies like Balassa (1978), Choi (1983), and Ram (1985). They modeled the contribution of export to economic growth that can explain the effect of exchange rate on growth through the exports. Also, effects of exchange rate appreciation on export expansion examined by studies such as Balogun (2007) for some African countries, Saadiah and Kamaruzaman (2008) for South-East Asian countries, Eichengreen and Gupta (2012) for South Korea, and Xiangqian and Guoqiang (2005) for China which concluded the exchange rate appreciation positively affects export and consequently will increase output. Recent researches like Choi and Pyun (2018) show that depreciation of national currency increases the productivity in export oriented industries and the more export oriented the firms are, the greater is the productivity increase.

According to economic theories, direction and strength of the exchange rate effect on output depend on sectoral and environmental conditions. In this regards, some studies have focused on the predictability of exchange rate movements. By using data of 23 countries, Agenor (1995) theoretically and empirically shows that predictable real exchange rate movements negatively affect output, while unpredictable real exchange rate movements positively stimulate output. Kamin and Rogers (2000), based on a VAR model, get to similar results for Mexico.

Several studies have emphasized the role of macroeconomic environment in the relationship between exchange rate and output. They examine this relationship across countries to identify effects of macroeconomic variables. Galindo et al (2007) investigated effects of depreciation of national currency in 9 Latin American countries and concluded that depreciation will increase employment level of industries. Based on this research, the degree of economic openness and dollarization of economy impress the relation between 
national currency's depreciation and employment. Burgess and Knetter (1998) find that exchange rate effects on employment in G-7 countries are significant and vary across countries. According to their findings, industries of France and Germany are much less affected by exchange rate shocks and much slower adjusted to long-run steady states, while employment in other countries (United States, Japan, Canada, United Kingdom and Italy) adjusted more quickly.

Other fields of research investigate the exchange rate effects on real sector performance by using data in industry level which has two advantages. First, the problem of endogeneity in the relationship between the exchange rate and economic growth in the macro-level is not critical in industry-level (Eichengreen ,2007). Second, possibility of sectoral analyzing of this relationship provides more accurate results because of considering industries specific characteristics in this relationship. Branson and Love (1988) and Revenga (1992) were the leading studies which investigate effects of exchange rate on industries' employment. Eichengreen (2007), using 28 industries data in 40 emerging countries, concluded that exchange rate significantly impacts the production growth of industries. Dhasmana (2015) using a Panel VAR model, investigated the effects of real exchange rate fluctuations on the performance of Indian industries and concluded that exchange rate changes significantly affect the performance of industries, and factors such as degree of market power, access to internal finance, and concentration level of industry affect the relationship between exchange rate movement and real performance of industries.

Another related avenue of research concentrates on the effects of exchange rate volatility on the real sector performance. Studies like Staneik (2007), Schnabl (2008), and Aliyu (2009), for different countries, have shown the effect of exchange rate volatility on economic growth is negative. Aghion et al (2009) concluded that exchange rate volatility decrease productivity and economic growth. This negative effect is more severe where the financial markets are less developed.

Our novel approach in the paper is that we examine heterogeneity of the exchange rate effects on production and employment of industries by considering the role of industries' characteristics. Having a rich data of 96 industries, we can identify the effects of exchange rate on production and employment in each industry subject to its specific characteristics.

\section{Data and Methodology}

\subsection{Data Description}

We test our hypothesis about the relationship between exchange rate fluctuations and production growth in different industries using a dataset consisting three data sources. First, we collect a quarterly time series data of macroeconomic variables such as exchange rate (US \$/Iran Rial) in spot market and consumer price index (CPI) published by Central Bank of Iran (CBI) for the periods of 2011q2 to 2017q1. Then, we estimate exchange rate volatility using GARCH $(1,1)$ based on this exchange rate data. Moreover, we calculate the growth of consumer price index and the growth of US \$ to Rial (as a proxy 
for exchange rate growth). The first panel of Table 1 presents the summary statistics of these variables. According to this table, the average quarterly growth of exchange rate is $5.981 \%$ and its standard deviation is 11.88 , which shows this key variable has an increasing trend with high volatility during that period. Furthermore, average of CPI growth is $4.591 \%$ and its standard deviation is 2.79 . Comparing the exchange rate growth and CPI growth indicates the exchange rate rises up faster than the consumer price index.

The second data source is industry-level data which contains production index, employment index, and wage index of 4-digit ISIC industries for the periods of 2011q2 to 2017q1. This data has been extracted from the CBI's survey which covers all Iranian manufacturing establishments with 100 or more employees. We calculate the industrial production index growth, employment growth and wage growth for 96 manufacturing industries in 24 quarters. The second panel of Table 1 shows data description of these variables. Accordingly, although the average growth of employment between industries is negative and near to zero, the average of production index growth is about 1.24 percent. Also the average growth of wage index in the sample is 0.5 percent higher than CPI growth.

In order to investigate the relationship between the industries production growth and exchange rate, we needed more variables to describe the industries properties and because latest data source did not include such variables, we add the third data source. Statistical Center of Iran (SCI) is publishing this dataset that covers all the Iranian manufacturing establishments with 10 or more employees (Although the second dataset is a subset of the third one, more than 80 percent of production value of firms in the third dataset (more than 10 employees) belong to firms in the second dataset (more than 100 employees)). This dataset contains variables that describe characteristics of industries annually for the period of 2011 to 2015 . These variables are reported for 4-digit ISIC industries and include investment properties, input and output inventories, ownership and management structure, number of active firms, degree of import dependency, and degree of export orientation. The last panel of Table 1 reports summary statistics of these variables.

\section{Table 1- Data description for variables}

\begin{tabular}{|c|c|c|c|c|c|}
\hline \multicolumn{2}{|c|}{ Variable name } & & Obs. N. & Aver. & St. Dev. \\
\hline \multirow{3}{*}{ 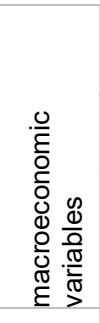 } & Exchange rate (US \$/ Iran Rial) growth (\%) & quarterly & 24 & 5.98 & 11.88 \\
\hline & Exchange rate Volatility (Extracted from GARCH) & quarterly & 24 & 0.0046 & 0.0083 \\
\hline & CPI growth (\%) & quarterly & 24 & 4.59 & 2.72 \\
\hline \multirow{3}{*}{ 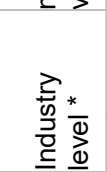 } & Production index growth (\%) & quarterly & 2304 & 1.24 & 19.83 \\
\hline & Employment index growth (\%) & quarterly & 2304 & -0.28 & 4.85 \\
\hline & Wage index growth (\%) & quarterly & 2304 & 5.1 & 17.07 \\
\hline 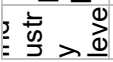 & Private ownership ratio (\%)(in terms of firms number) & annually & 336 & 96.86 & 5.02 \\
\hline
\end{tabular}




\begin{tabular}{|l|l|l|l|l|}
\hline Private ownership ratio (\%)(in terms of employment) & annually & 336 & 93.97 & 10.26 \\
\hline $\begin{array}{l}\text { Private management ratio (\%)(in terms of firms } \\
\text { number) }\end{array}$ & annually & 336 & 96.93 & 5.02 \\
\hline $\begin{array}{l}\text { Number of firms in the industries } \\
\text { Export to output ratio (\%) }\end{array}$ & annually & 336 & 121.05 & 167.09 \\
\hline $\begin{array}{l}\text { Investment to output (\%) } \\
\text { Emnually }\end{array}$ & 336 & 22.22 & 28.29 \\
\hline $\begin{array}{l}\text { Foreign capital goods expenditure (\% of total capital } \\
\text { goods expenditure) }\end{array}$ & annually & 336 & 4.32 & 7.49 \\
\hline $\begin{array}{l}\text { Imported inputs (\% of total input) } \\
\text { Inventories to output (\%) }\end{array}$ & annually & 336 & 17.03 & 12.047 \\
\hline Logarithm of fixed capital formation (investment) & annually & 336 & 65.06 & 33.10 \\
\hline
\end{tabular}

* Data source of these variables is survey of manufacturing establishment with 100 or more employees which is collected by central bank of Iran quarterly.

** Data source of these variables is survey of manufacturing establishment with 10 or more employees which is collected by Statistical center of Iran annually

Economic sanctions against Iran imposed by US and EU in 2011 and 2012 led to limit access to foreign currencies in Iran. These restrictions caused a currency crisis and value of the national currency (Rial) devalued more than $119 \%$ since autumn 2011 to winter 2013. As shown in Figure 1 the exchange rate growth and volatility dramatically higher in this periods (autumn 2011 to winter 2013) relative to other study periods. Since the sanctions are the cause of higher exchange rate growth in that periods and higher growth is a sign for deeper crisis, increase in exchange rate growth in the crisis periods can interpret differently from the increase in exchange rate in ordinary periods. So we consider this difference in modeling of the exchange rate effect on production.

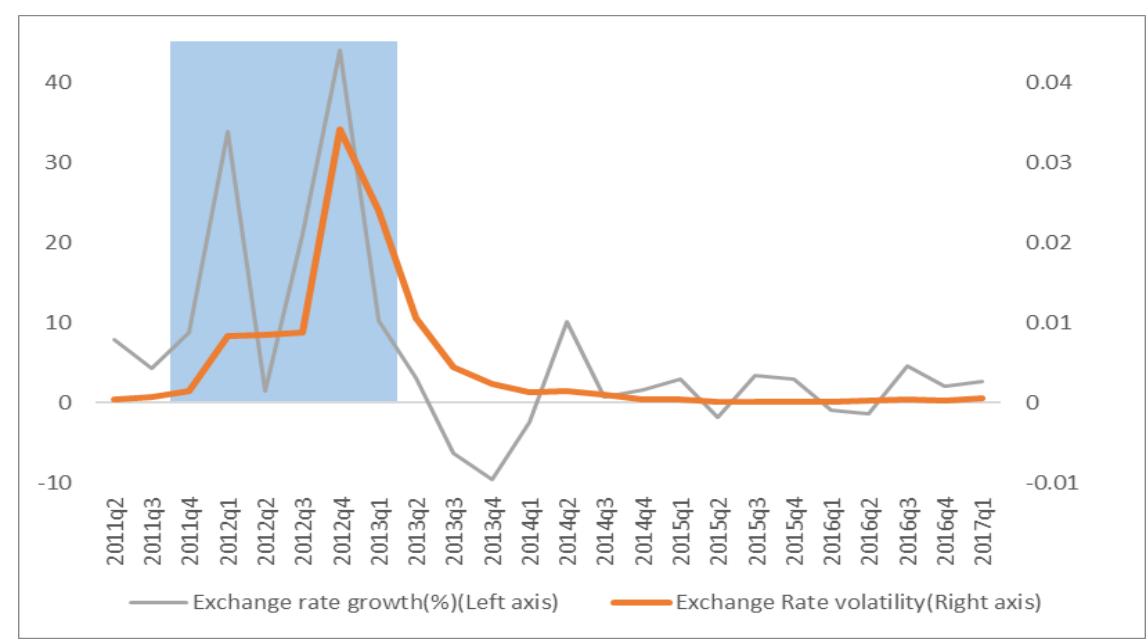

Fig. 2. Exchange rate growth and volatility in the currency crisis periods and after that

* Shadow area indicates periods that exchange rate growth and volatility were extremely high. We define these periods as a currency crisis periods.

According to data, in terms of employment, 94 percent of manufacturing firms, and in terms of production, 97 percent of them have private management. The strength of link 
with foreign economies is a key determinant for effectiveness of exchange rate in the industries. In this paper, the link with foreign economies is measured by three benchmarks. Foreign capital goods expenditure to total capital expenditure, exported output to total output (Exported output to total output ratio is a measure of export orientation. Industries that have higher ratios are more export oriented), and imported input to total input are three benchmarks that used for measuring the strength of industries dependence on foreign parties and consequently exchange rates. According to the sample data the average of foreign capital goods expenditure ratio, exported output ratio and imported input ratio are $11.85,22.2$, and 17.03 percent respectively. Also large standard deviations of these benchmarks show high level of dispersion of these variables among the industries.

Figure 2 shows the unconditional correlation between exchange rate growth and production growth varies across the industries and the variation range is quite large (from 0.53 to -0.49). Moreover, although in the most industries the unconditional correlation between the exchange rate volatility and production growth is negative, according to the figure, there are differences in productions with response to exchange rate volatility among the industries. So to understand the cause of these differences, we estimate the conditional relationship between exchange rate growth, volatility and production growth and identify the effects of some key features on these relationships.

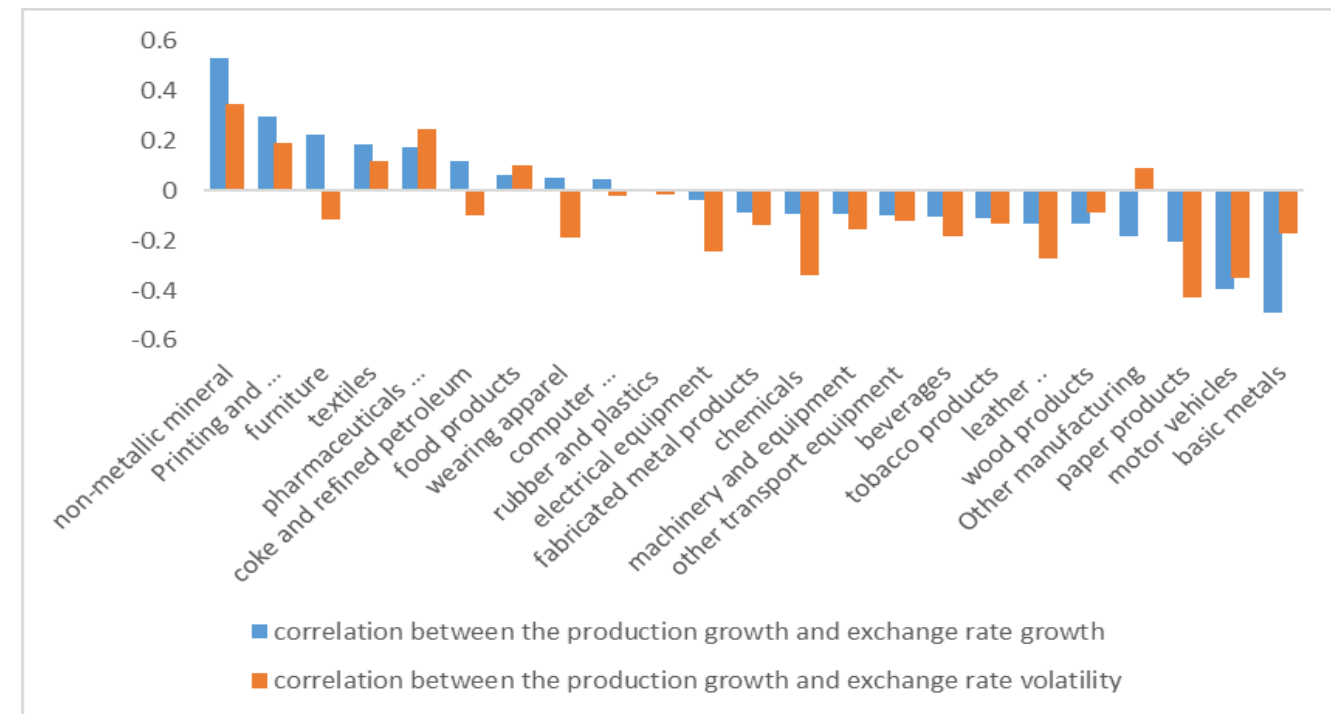

Fig. 2 the correlation coefficient of production growth and exchange rate between industries in the selected sample periods (2011-2017q1)

\subsection{Empirical Framework}

To examine the relationship between production growth and exchange rate growth we use an empirical model based on the theoretical suggestion presented in previous section. According to literature and theoretical basis, we estimate below equations, where 4-digit ISIC industries are indexed by $i$ and time by $t$ (It should be noted that frequency of all data in these models, except investment (log of fixed capital formation) is quarterly.) : 
Prod $_{i t}=\alpha_{0}+\alpha_{2}$ Prod $_{i t-1}+\sum_{n=0}^{2} \varphi_{n} \varepsilon m p_{i t-n}+\sum_{n=0}^{2} \omega_{n} K_{i t-n}+\sum_{n=0}^{2} \beta_{n} R E R_{t-n}+$ $\sum_{n=0}^{2} \gamma_{n} V E R_{t-n}+\sum_{n=0}^{2} \theta_{n} \pi_{t-n}+a_{1} y q_{t}+u_{i t}$

Prodit $_{\text {it }}$

Where denotes production growth in industry $\mathrm{i}$ and quarter $\mathrm{t}$, used as $e m p_{i t}$

dependent variable in equation (8) and represents employment growth which is an $K_{\mathrm{it}}$

explanatory variable in equation (8). Also, stand for logarithm of fixed capital formation. $R E R_{\mathrm{t}} \quad V E R_{\mathrm{t}}$

Moreover, and denote real exchange rate (US $\$$ / Iran Rial) growth in spot market and exchange rate volatility (that extracted from $\operatorname{GARCH}(1,1)$ model). We also $y q_{t}$

control on year fixed effects ( ). Additionally, we use lags of dependent variable in each equation as an independent variable. Since economic variables effects often are accompanied by lag, to capture all dynamic effects, two lags of independent variables are used in the model. The number of optimal lags came from Akaike information criterion (AIC) and Schwarz information criterion (SIC) (Since only available data for investment in 4-digit ISIC is annual and other quarterly variables appear in the model with two lags, for investment we use annual data without any lag).

The equations represented in a panel data framework contain lags of dependent variables as independent variable. So, the consistent estimation as presented in Arellano and Bond (1991), is Dynamic Panel GMM method which uses lag of explanatory variables as instrumental variables (IV) as a proxy for the dependent variable's lag. For choosing optimal instrumental variables we use Sargan's $J$ test and Hansen test which test overidentifying restrictions (A test of over-identifying restrictions regresses the residuals from the regression on all instruments. Under the null hypothesis that all instruments are uncorrelated with residuals).

Equations (8) examines the effects of exchange rate growth and volatility on industries' production growth. Since the effect of exchange rate movement on outputs in the currency crisis is not same as usual condition, we introduce a dummy variables for the crisis periods $2011 q 4$ to $2013 q 1$ and insert interaction of the dummy and exchange rate to equation to examine whether exchange rate growth differently influence on output growth in the crisis periods.

According to the literature, the relationship between exchange rate movements and production growth varies across the industries. So, in order to identify the effects of industries' characteristics (such as import dependency, export orientation, ownership structure, and inventories) in this relationship, we add interaction terms to these equations (In contrast to quarterly data of dependent variable, industry characteristics are annual and they might drastically change in each year. Also, data periods do not completely overlap). The interaction term for a characteristic of industries, which can be calculated by multiplying the exchange rate growth by that characteristic, shows how the relationship between dependent variable (production growth) and exchange rate can be influenced by 
that specific characteristic. Note that adding the characteristic variable as a separate variable is required to correct identification of the interaction term's effect.

\section{Estimation Results}

Table 2 reports estimation results of equation (8) which examine the relationship between exchange rate growth and the production growth. In the first column, the model involve one lag of dependent variable, real exchange rate growth and its two lags, and exchange rate volatility and its two lags as explanatory variables. To calculate the overall effects of exchange rate growth, we aggregate significant coefficients of exchange rate growth and its lags. Overall effects of exchange rate volatility also calculate with same process. We also estimate the model with two lags of dependent variables which reported in the second column. In first and second estimations of Table 2, we exclude the currency crisis periods (2011q4 to $2013 q 1$ ). The estimation reported in the column (3) is same as the first column and the difference is that column (3) include the currency crisis periods. Also, to measure the effect of the crisis, we insert interaction term between exchange rate growth and the crisis dummy variable into the model. The column (4) presents column (3) estimation with two lags of dependent variable.

According to the results of first and second estimations in table 2, in non-crisis periods real exchange rate growth has significant positive effects on industries' production growth. The positive effect of exchange rate remain significant until two lags. So real exchange rate depreciation in non-crisis periods, through improvement of the competitiveness, lead to increase in industries growth in Iran. When a currency crisis happening this relationship changes dramatically. As reported in columns (3) and (4), since interaction terms of real exchange rate growth and the crisis dummy are negative and significant (in the second lag) in both estimations, aggregate effect of exchange rate on industrial production in the crisis periods (which is calculated from aggregation of exchange rate growth and its lags coefficients and the interaction terms coefficients) do not significantly differ from zero. So although the real deprecation in non-crisis period can induce increase in production growth among the Iranian industries, but the positive effect of the real exchange rate growth is eliminated in the crisis periods. As we will show in the next tables, the effect of exchange rate is not same across the industries due to the difference in mechanisms that exchange rate affects the industries.

Moreover, according to all four estimations of Table 2, the aggregate effects of the exchange rate volatility on the production growth, which is obtained by aggregating the significant effects, are negative. It means although an increase in exchange rate growth leads to rising up the production growth, an increase in exchange rate volatility on average has negative effects on production growth. Note that the exchange rate volatility impact negatively on the production growth with lag ( based on (1) and (2) estimations with one lag and based on (3) and (4) estimations with two lags.

As explained, our main hypothesis is that different industries with disparate features, are impacted differently, so considering the difference in key determinant characteristics (like labor or capital intensity, degree of dependence on export or import, management and ownership structure and so on) helps explain these distinct impacts of 
exchange rate across industries. Tables 3 to 6 address to estimations considering industries characteristics as interaction terms. All these tables divided in two part and each part explore the effect of one characteristics which include two estimations. First estimation in each part contains one lag of dependent variables and second estimation contains two lag of dependent variables as explanatory variables.

Table 2: Estimation results of the production growth

\begin{tabular}{|c|c|c|c|c|}
\hline \multirow[b]{2}{*}{ VARIABLES } & \multicolumn{4}{|c|}{ Dependent Variable: Production Growth(Prod $\left.{ }_{i t}\right)$} \\
\hline & (1) & $(2)$ & (3) & $(4)$ \\
\hline & $-0.189^{* * *}$ & -0.0691 & $-0.217^{* * *}$ & -0.0597 \\
\hline \multirow[t]{2}{*}{ Prod $_{\mathrm{it}-1}$} & $(0.0597)$ & $(0.0896)$ & $(0.0691)$ & $(0.110)$ \\
\hline & & $0.139^{*}$ & & $0.159^{\star *}$ \\
\hline \multirow[t]{2}{*}{ Prod $_{\mathrm{it}-2}$} & & $(0.0739)$ & & $(0.0811)$ \\
\hline & $5.738^{\star * *}$ & $5.269^{* * *}$ & $4.283^{* *}$ & $3.942^{*}$ \\
\hline \multirow[t]{2}{*}{$\mathrm{RER}_{\mathrm{t}}$} & $(1.543)$ & $(1.669)$ & $(1.839)$ & $(2.033)$ \\
\hline & $4.341^{* \star *}$ & $3.782^{* *}$ & 1.889 & 1.371 \\
\hline \multirow[t]{2}{*}{$\mathrm{RER}_{\mathrm{t}-1}$} & $(1.499)$ & $(1.625)$ & $(1.509)$ & $(1.684)$ \\
\hline & $5.422^{* \star *}$ & $5.320^{* * *}$ & $4.556^{* * *}$ & $4.514^{* * *}$ \\
\hline \multirow[t]{2}{*}{$\mathrm{RER}_{\mathrm{t}-2}$} & $(1.218)$ & $(1.300)$ & $(1.567)$ & $(1.727)$ \\
\hline & & & -16.40 & -13.21 \\
\hline \multirow[t]{2}{*}{ Crisis_dummy ${ }_{t}^{*} R R_{t}$} & & & $(22.93)$ & $(25.31)$ \\
\hline & & & -15.22 & -13.28 \\
\hline \multirow[t]{2}{*}{ Crisis_dummy $\mathrm{y}_{\mathrm{t}-1}{ }^{\star} \mathrm{RE} \mathrm{R}_{\mathrm{t}-1}$} & & & $(14.90)$ & (16.44) \\
\hline & & & $-8.984^{* * *}$ & $-8.716^{\star *}$ \\
\hline \multirow[t]{2}{*}{ Crisis_dummy $y_{t-2}{ }^{*} R_{E} R_{t-2}$} & & & $(3.145)$ & $(3.467)$ \\
\hline & 14.42 & 12.36 & 13.59 & 10.77 \\
\hline \multirow[t]{2}{*}{$\mathrm{VER}_{\mathrm{t}}$} & (18.39) & $(19.83)$ & $(25.10)$ & $(27.70)$ \\
\hline & $-35.15^{\star * *}$ & $-33.03^{* *}$ & 4.121 & 5.040 \\
\hline \multirow[t]{2}{*}{$V_{E R} R_{t-1}$} & $(12.63)$ & $(13.56)$ & $(6.946)$ & (7.667) \\
\hline & $9.352^{\star * *}$ & $8.801^{* \star *}$ & $-6.362^{* \star *}$ & $-6.262^{* * *}$ \\
\hline \multirow[t]{2}{*}{$\mathrm{VER}_{\mathrm{t}-2}$} & $(2.633)$ & $(2.825)$ & $(2.123)$ & $(2.340)$ \\
\hline & -0.744 & -1.323 & $-2.900^{*}$ & -3.082 \\
\hline \multirow[t]{2}{*}{$\mathrm{emp}_{\mathrm{it}}$} & $(1.779)$ & $(2.058)$ & $(1.744)$ & $(1.924)$ \\
\hline & $2.333^{*}$ & $2.381^{*}$ & 1.673 & 1.708 \\
\hline \multirow[t]{2}{*}{$\mathrm{emp}_{\mathrm{it}-1}$} & $(1.215)$ & $(1.303)$ & $(1.217)$ & $(1.341)$ \\
\hline & $-4.140^{\star \star \star}$ & $-4.369^{\star \star *}$ & $-3.440^{* \star *}$ & $-4.000^{* * *}$ \\
\hline \multirow[t]{2}{*}{$\mathrm{emp}_{\mathrm{it}-2}$} & (1.171) & $(1.256)$ & $(1.236)$ & $(1.392)$ \\
\hline & 2.215 & 1.050 & 2.749 & 2.174 \\
\hline \multirow[t]{2}{*}{$\mathrm{K}_{\mathrm{it}}$} & $(3.054)$ & $(3.350)$ & $(2.781)$ & $(3.078)$ \\
\hline & $538.2^{\star \star *}$ & $548.2^{* * *}$ & 349.1 & 303.1 \\
\hline Constant & $(165.0)$ & $(176.7)$ & $(507.0)$ & $(559.1)$ \\
\hline Time-fixed Effect & Yes & Yes & Yes & Yes \\
\hline Observations & 1,000 & 1,000 & 1,405 & 1,405 \\
\hline Number of isic & 85 & 85 & 85 & 85 \\
\hline
\end{tabular}

${ }^{*}$ Robust standard errors are reported in parentheses. ${ }^{* \star *},{ }^{* \star},{ }^{*}$ denote significance at $1 \%, 5 \%$ and $10 \%$ levels respectively.

As described, in the estimated model reported in tables 3 to 6 we add two groups of variables to the main specification. First, the interaction term of industries' 
characteristics and the exchange rate growth and its lags (for example, interaction term for export orientation is obtained by multiplying the exported output ratio by exchange rate growth). Note that to recognize the pure effect of these characteristics on the relationship between the exchange rate growth and industries production growth we need to control the effect of these characteristics on the production growth. Then, second group of variables that have been added to the model are these characteristics as a separate variable (For example when we want to estimate the effects of export orientation interaction terms, we should control the effect of degree of export orientation on production growth distinctly).

First part in Table 3 reports estimations which contains industries' degree of export orientation (export to output ratio in each industry) and its interaction with exchange rate growth. Similar to the main specification estimations, the direct effect of exchange rate growth on the production growth is positive and significant. Since the coefficients of interaction terms of export orientation and exchange rate growth are significant and positive, we can conclude that the dependence on export market is an important determinant of relationship between industries' growth and exchange rate. So, real depreciation of local currency (Rial) leads to a rise in the industrial production growth and this effect will be amplified in industries with higher degrees of export orientation. This result is robust to vary the number of dependent variable lags.

Note that the exchange rate regime in Iran in the study periods was dual exchange rate regime and some industry segments (mostly industries that produce essential goods) accessed to preferential exchange rate (Because of state subsidizes, foreign currencies prices for these industries were cheaper than spot market prices). In second part of table 3 (estimation (3) and (4)), we examine the contribution of industries' assessment to the preferential exchange rate in the relationship between the production growth and real exchange rate growth. The estimated coefficients of the interaction terms in estimation (3) reveal the positive relationship between the exchange rate growth and production growth is stronger among the industries that access to preferential exchange rate. In other words, when a real exchange rate depreciation occurs, the output growth in industries that access to this state subsidized exchange rate increases more than others. According to the estimation (4), this result also remains valid with adding second lag of dependent variable as an explanatory variable.

Table 3. Role of export orientation and access to the preferential rate in the exchange rate effects among industries 


\begin{tabular}{|c|c|c|c|c|}
\hline \multirow{2}{*}{$\begin{array}{l}\text { Cross variables } \\
\text { Dep. Var.: Prodit }\end{array}$} & \multicolumn{2}{|c|}{ Export Orientation } & \multicolumn{2}{|c|}{$\begin{array}{l}\text { Access to the } \\
\text { preferential rate }\end{array}$} \\
\hline & (1) & $(2)$ & (3) & (4) \\
\hline Prodit-1 $_{\text {in }}$ & $\begin{array}{l}-0.263^{* * *} \\
(0.0788)\end{array}$ & $\begin{array}{l}-0.0987 \\
(0.118)\end{array}$ & $\begin{array}{l}-0.364^{* * *} \\
(0.0726)\end{array}$ & $\begin{array}{l}-0.262^{* * *} \\
(0.0978)\end{array}$ \\
\hline Prodit-2 & & $\begin{array}{l}0.201^{* *} \\
(0.100)\end{array}$ & & $\begin{array}{c}0.138 \\
(0.0847)\end{array}$ \\
\hline $\mathrm{RER}_{\mathrm{t}}$ & $\begin{array}{c}1.066 \\
(1.633)\end{array}$ & $\begin{array}{c}0.826 \\
(1.769)\end{array}$ & $\begin{array}{l}-0.0839 \\
(3.329)\end{array}$ & $\begin{array}{c}0.161 \\
(3.464)\end{array}$ \\
\hline $\mathrm{RER}_{\mathrm{t}-1}$ & $\begin{array}{l}3.415^{* *} \\
(1.589)\end{array}$ & $\begin{array}{l}3.211^{*} \\
(1.721)\end{array}$ & $\begin{array}{l}2.329 \\
(2.165)\end{array}$ & $\begin{array}{l}2.099 \\
(2.255)\end{array}$ \\
\hline $\mathrm{RER}_{\mathrm{t}-2}$ & $\begin{array}{c}0.890 \\
(1.370)\end{array}$ & $\begin{array}{c}1.347 \\
(1.498)\end{array}$ & $\begin{array}{l}-1.940 \\
(2.258)\end{array}$ & $\begin{array}{l}-1.473 \\
(2.364)\end{array}$ \\
\hline (export to output) it & $\begin{array}{c}13.65 \\
(50.53)\end{array}$ & $\begin{array}{c}21.21 \\
(54.75)\end{array}$ & & \\
\hline (export to output) it ${ }^{*} R E R_{t}$ & $\begin{array}{l}10.71^{*} \\
(6.291)\end{array}$ & $\begin{array}{l}12.90^{*} \\
(6.887)\end{array}$ & & \\
\hline (export to output) it-1 ${ }^{*} R R_{t-1}$ & $\begin{array}{l}-6.818 \\
(5.894)\end{array}$ & $\begin{array}{l}-6.620 \\
(6.371)\end{array}$ & & \\
\hline (export to output) it-2 ${ }^{*} R E R_{t-2}$ & $\begin{array}{l}9.396^{*} \\
(4.920)\end{array}$ & $\begin{array}{c}8.071 \\
(5.360)\end{array}$ & & \\
\hline (Access to The Preferential Rate) it & & & $\begin{array}{l}8.790 \\
(37.80)\end{array}$ & $\begin{array}{c}17.76 \\
(39.68)\end{array}$ \\
\hline (Access to The Preferential Rate) ${ }_{\text {it }}{ }^{*} R E R_{t}$ & & & $\begin{array}{c}6.872 \\
(6.970)\end{array}$ & $\begin{array}{c}6.667 \\
(7.246)\end{array}$ \\
\hline (Access to The Preferential Rate) it-1 $^{*} R E R_{t-1}$ & & & $\begin{array}{l}-0.820 \\
(4.222)\end{array}$ & $\begin{array}{l}-0.560 \\
(4.392)\end{array}$ \\
\hline (Access to The Preferential Rate) ${ }_{i t-2}{ }^{*} R E R_{t-2}$ & & & $\begin{array}{l}10.17^{* *} \\
(4.659)\end{array}$ & $\begin{array}{c}9.397^{*} \\
(4.866)\end{array}$ \\
\hline VER $R_{t}$ & $\begin{array}{c}18.40 \\
(13.33)\end{array}$ & $\begin{array}{c}19.18 \\
(14.42)\end{array}$ & $\begin{array}{c}10.93 \\
(12.29)\end{array}$ & $\begin{array}{c}11.25 \\
(12.78)\end{array}$ \\
\hline$V_{E R} R_{t-1}$ & $\begin{array}{c}-24.28^{* * *} \\
(8.988)\end{array}$ & $\begin{array}{c}-25.47^{* * *} \\
(9.733)\end{array}$ & $\begin{array}{c}-19.49^{* *} \\
(8.183)\end{array}$ & $\begin{array}{c}-20.07^{* *} \\
(8.513)\end{array}$ \\
\hline$V_{E R} R_{-2}$ & $\begin{array}{c}6.100^{* * *} \\
(1.834)\end{array}$ & $\begin{array}{c}6.581^{* * *} \\
(1.997)\end{array}$ & $\begin{array}{c}5.200^{* * *} \\
(1.650)\end{array}$ & $\begin{array}{c}5.414^{* * *} \\
(1.720)\end{array}$ \\
\hline empit & $\begin{array}{l}-2.326 \\
(2.261)\end{array}$ & $\begin{array}{l}-2.988 \\
(2.467)\end{array}$ & $\begin{array}{l}-1.151 \\
(2.434)\end{array}$ & $\begin{array}{c}-1.488 \\
(2.538)\end{array}$ \\
\hline emp $\mathrm{it}_{\mathrm{it}-1}$ & $\begin{array}{c}3.331^{\star} \\
(1.766)\end{array}$ & $\begin{array}{l}4.090^{* *} \\
(1.946)\end{array}$ & $\begin{array}{l}2.444^{*} \\
(1.470)\end{array}$ & $\begin{array}{c}2.910^{\star} \\
(1.555)\end{array}$ \\
\hline empit-2 & $\begin{array}{c}-4.024^{* *} \\
(1.636)\end{array}$ & $\begin{array}{c}-4.415^{\star *} \\
(1.780)\end{array}$ & $\begin{array}{c}-3.840^{* * *} \\
(1.401)\end{array}$ & $\begin{array}{c}-4.262^{* * *} \\
(1.480)\end{array}$ \\
\hline $\mathrm{K}_{\mathrm{it}}$ & $\begin{array}{c}1.546 \\
(5.844)\end{array}$ & $\begin{array}{l}-0.764 \\
(6.421)\end{array}$ & $\begin{array}{c}8.446^{*} \\
(4.828)\end{array}$ & $\begin{array}{c}6.110 \\
(5.219)\end{array}$ \\
\hline Constant & $\begin{array}{c}218.7^{*} \\
(126.2)\end{array}$ & $\begin{array}{l}263.7^{*} \\
(138.3)\end{array}$ & $\begin{array}{c}155.7 \\
(117.4) \\
\end{array}$ & $\begin{array}{r}190.9 \\
(123.9) \\
\end{array}$ \\
\hline Time-fixed Effect & Yes & Yes & Yes & Yes \\
\hline Observations & 960 & 960 & 928 & 928 \\
\hline Number of isic & 81 & 81 & 78 & 78 \\
\hline
\end{tabular}

Robust standard errors are reported in parentheses. ${ }^{* * *},{ }^{* *},{ }^{*}$ denote significance at $1 \%, 5 \%$ and $10 \%$ levels respectively

Because private and state owned firms may adopt disparate pricing and production strategies, their responses to exchange rate shocks might be different. So, first part of Table 4 shows the results considering ownership structure effects. In this order, we 
enter industries' ownership structure variable (which is defined as Private Ownership Ratio (\%) in Terms of Employment)) and also its interaction with the exchange rate growth as independent variables. According to the estimation (1), the lag of interaction terms has significant and positive effect that shows an increase in exchange rate growth (depreciation) have stronger (positive) effect in the industries with higher percentage of private firms. Although since this result do not remain valid in the estimation (2) (which includes two lags of dependent variable. The coefficient of first lag of the interaction between exchange rate growth and ownership is positive and significant and the second lag of the interaction has negative and significant effect that nullifies the first lag effect.), it can be concluded the effect of ownership structure is not robust across the specifications.

Second part of Table 4 explore the impact of degree of import dependency on the relationship between exchange rate growth and industry production growth across the industries (To calculate the import dependency index, we consider foreign raw materials and capital goods. So, the import dependency index is the sum of percent of imported raw materials to total raw materials and percent of imported capital goods to total investment). According to estimation results in both estimation (3) and (4), first lag of interaction terms has a significant negative coefficient, which substantiates exchange rate growth will decrease the production of firms that are more dependent on import. We can calculate a threshold to find which industries are negatively affected by the exchange rate shocks (According to regression specification, total effect of exchange rate growth could be calculated by the reduced equation $(a+b x) R E R$ where "a" is the direct effect of exchange rate and "b" is the interacted effect of $x R E R$ ( $x$ is the industry characteristic like import dependency index). If $x$ equals $-a / b$ the effect of exchange rate growth will be zero, so the exact threshold is $x$ ). To find the threshold, sum of significant coefficients of the exchange rate (a math equation is here) must be divided to sum of significant coefficients of interaction terms. According to this calculation, less than 5 percent of Iranian industries are effected negatively by exchange rate depreciation. 
Table 4. Role of ownership structure and import dependency in the exchange rate effects among industries

\begin{tabular}{|c|c|c|c|c|}
\hline \multirow{2}{*}{$\begin{array}{l}\text { Cross Variables: } \\
\text { Dep. Var.: Prod }{ }_{i t}\end{array}$} & \multicolumn{2}{|c|}{ Ownership structure } & \multicolumn{2}{|c|}{ Import dependency } \\
\hline & $(1)$ & $(2)$ & $(3)$ & $(4)$ \\
\hline Prod $_{i t-1}$ & $\begin{array}{l}-0.158^{* *} \\
(0.0711)\end{array}$ & $\begin{array}{l}0.0213 \\
(0.121)\end{array}$ & $\begin{array}{c}-0.187^{\star * *} \\
(0.0633)\end{array}$ & $\begin{array}{l}0.0141 \\
(0.106)\end{array}$ \\
\hline Prod $_{i t-2}$ & & $\begin{array}{c}0.185^{* *} \\
(0.0936)\end{array}$ & & $\begin{array}{l}0.213^{* * *} \\
(0.0822)\end{array}$ \\
\hline $\mathrm{RER}_{\mathrm{t}}$ & $\begin{array}{c}15.78 \\
(10.41)\end{array}$ & $\begin{array}{l}14.68 \\
(11.70)\end{array}$ & $\begin{array}{c}3.033 \\
(3.182)\end{array}$ & $\begin{array}{l}3.620 \\
(3.605)\end{array}$ \\
\hline $\mathrm{RER}_{\mathrm{t}-1}$ & $\begin{array}{l}-13.26 \\
(8.397)\end{array}$ & $\begin{array}{l}-14.51 \\
(9.447)\end{array}$ & $\begin{array}{l}6.164^{* * *} \\
(1.863)\end{array}$ & $\begin{array}{c}5.603^{* * *} \\
(2.117)\end{array}$ \\
\hline $\mathrm{RER}_{\mathrm{t}-2}$ & $\begin{array}{l}15.15^{\star \star} \\
(6.699)\end{array}$ & $\begin{array}{l}20.07^{* *} \\
(7.918)\end{array}$ & $\begin{array}{l}3.880^{* *} \\
(1.632)\end{array}$ & $\begin{array}{c}2.779 \\
(1.893)\end{array}$ \\
\hline (Private Ownership) it & $\begin{array}{c}0.397 \\
(0.606)\end{array}$ & $\begin{array}{l}-0.0142 \\
(0.711)\end{array}$ & & \\
\hline (Private Ownership) it $^{\star} R E R_{t}$ & $\begin{array}{l}-0.106 \\
(0.107)\end{array}$ & $\begin{array}{r}-0.0952 \\
(0.120)\end{array}$ & & \\
\hline (Private Ownership) $_{\text {it-1 }}{ }^{\star} \mathrm{RER}_{\mathrm{t}-1}$ & $\begin{array}{l}0.176^{\star \star} \\
(0.0828)\end{array}$ & $\begin{array}{l}0.185^{* *} \\
(0.0931)\end{array}$ & & \\
\hline (Private Ownership) ${ }_{\text {it-2 }}{ }^{*} R R_{t-2}$ & $\begin{array}{c}-0.102 \\
(0.0665)\end{array}$ & $\begin{array}{l}-0.150^{*} \\
(0.0785)\end{array}$ & & \\
\hline (Import dependency) it & & & $\begin{array}{l}-0.636 \\
(0.552)\end{array}$ & $\begin{array}{l}-0.818 \\
(0.628)\end{array}$ \\
\hline (Import dependency) it ${ }^{*} R R_{t}$ & & & $\begin{array}{c}0.0730 \\
(0.0879)\end{array}$ & $\begin{array}{l}0.0360 \\
(0.100)\end{array}$ \\
\hline (Import dependency) it-1 $^{*} \mathrm{RER} \mathrm{R}_{\mathrm{t}-1}$ & & & $\begin{array}{l}-0.0674^{*} \\
(0.0370)\end{array}$ & $\begin{array}{l}-0.0723^{*} \\
(0.0419)\end{array}$ \\
\hline (Import dependency) $)_{\mathrm{it}-2}{ }^{*} \mathrm{RER}_{\mathrm{t}-2}$ & & & $\begin{array}{c}0.0363 \\
(0.0398)\end{array}$ & $\begin{array}{c}0.0709 \\
(0.0469)\end{array}$ \\
\hline VER $R_{t}$ & $\begin{array}{l}7.991 \\
(20.45)\end{array}$ & $\begin{array}{c}5.419 \\
(22.99)\end{array}$ & $\begin{array}{c}7.273 \\
(18.91)\end{array}$ & $\begin{array}{c}3.832 \\
(21.42)\end{array}$ \\
\hline $\mathrm{VER}_{\mathrm{t}-1}$ & $\begin{array}{c}-30.99^{* *} \\
(14.05)\end{array}$ & $\begin{array}{l}-30.44^{*} \\
(15.77)\end{array}$ & $\begin{array}{l}-29.83^{* *} \\
(12.72)\end{array}$ & $\begin{array}{l}-27.52^{*} \\
(14.41)\end{array}$ \\
\hline $\mathrm{VER}_{\mathrm{t}-2}$ & $\begin{array}{c}9.079^{* * *} \\
(2.989)\end{array}$ & $\begin{array}{c}8.990^{* * *} \\
(3.355)\end{array}$ & $\begin{array}{l}8.481^{* * *} \\
(2.666)\end{array}$ & $\begin{array}{c}8.107^{* * *} \\
(3.017)\end{array}$ \\
\hline $\mathrm{emp}_{\mathrm{it}}$ & $\begin{array}{l}-1.251 \\
(2.171)\end{array}$ & $\begin{array}{l}-1.939 \\
(2.462)\end{array}$ & $\begin{array}{l}-0.661 \\
(1.947)\end{array}$ & $\begin{array}{l}-1.587 \\
(2.230)\end{array}$ \\
\hline $\mathrm{emp}_{\mathrm{it}-1}$ & $\begin{array}{l}1.700 \\
(1.444)\end{array}$ & $\begin{array}{l}1.274 \\
(1.635)\end{array}$ & $\begin{array}{c}1.182 \\
(1.282)\end{array}$ & $\begin{array}{c}0.992 \\
(1.451)\end{array}$ \\
\hline $\mathrm{emp}_{\mathrm{it}-2}$ & $\begin{array}{c}-3.010^{* *} \\
(1.431)\end{array}$ & $\begin{array}{l}-3.432^{* *} \\
(1.620)\end{array}$ & $\begin{array}{c}-3.675^{\star \star *} \\
(1.221)\end{array}$ & $\begin{array}{c}-3.887^{* * *} \\
(1.383)\end{array}$ \\
\hline $\mathrm{K}_{\mathrm{it}}$ & $\begin{array}{c}2.005 \\
(3.610)\end{array}$ & $\begin{array}{l}-0.461 \\
(4.239)\end{array}$ & $\begin{array}{c}4.602 \\
(3.474)\end{array}$ & $\begin{array}{c}2.269 \\
(4.029)\end{array}$ \\
\hline Constant & $\begin{array}{c}549.5^{* * *} \\
(210.7) \\
\end{array}$ & $\begin{array}{c}656.8^{* * *} \\
(242.6) \\
\end{array}$ & $\begin{array}{c}547.0^{* * *} \\
(175.0)\end{array}$ & $\begin{array}{c}599.8^{* * *} \\
(198.9)\end{array}$ \\
\hline Time-fixed Effect & Yes & Yes & Yes & Yes \\
\hline Observations & 1,000 & 1,000 & 1,000 & 1,000 \\
\hline Number of isic & 85 & 85 & 85 & 85 \\
\hline
\end{tabular}

Robust standard errors are reported in parentheses. ${ }^{* * *},{ }^{* *},{ }^{*}$ denote significance at $1 \%, 5 \%$ and $10 \%$ levels respectively 
Table 5. Role of labor intensity and level of competitiveness in the exchange rate effects among industries

\begin{tabular}{|c|c|c|c|c|}
\hline \multirow{2}{*}{$\begin{array}{l}\text { Cross Variables: } \\
\text { Dep. Var.: Prod }_{\text {it }}\end{array}$} & \multicolumn{2}{|c|}{ Ownership structure } & \multicolumn{2}{|c|}{ Import dependency } \\
\hline & $(1)$ & $(2)$ & (3) & $(4)$ \\
\hline Prod $_{i t-1}$ & $\begin{array}{l}-0.158^{* *} \\
(0.0711)\end{array}$ & $\begin{array}{l}0.0213 \\
(0.121)\end{array}$ & $\begin{array}{l}-0.187^{* * *} \\
(0.0633)\end{array}$ & $\begin{array}{l}0.0141 \\
(0.106)\end{array}$ \\
\hline Prod $_{i-2}$ & & $\begin{array}{c}0.185^{* *} \\
(0.0936)\end{array}$ & & $\begin{array}{l}0.213^{* * *} \\
(0.0822)\end{array}$ \\
\hline $\mathrm{RER}_{\mathrm{t}}$ & $\begin{array}{c}15.78 \\
(10.41)\end{array}$ & $\begin{array}{c}14.68 \\
(11.70)\end{array}$ & $\begin{array}{c}3.033 \\
(3.182)\end{array}$ & $\begin{array}{c}3.620 \\
(3.605)\end{array}$ \\
\hline $\mathrm{RER}_{\mathrm{t}-1}$ & $\begin{array}{l}-13.26 \\
(8.397)\end{array}$ & $\begin{array}{l}-14.51 \\
(9.447)\end{array}$ & $\begin{array}{c}6.164^{* * *} \\
(1.863)\end{array}$ & $\begin{array}{c}5.603^{* * *} \\
(2.117)\end{array}$ \\
\hline $\mathrm{RER}_{\mathrm{t}-2}$ & $\begin{array}{l}15.15^{* *} \\
(6.699)\end{array}$ & $\begin{array}{l}20.07^{\star *} \\
(7.918)\end{array}$ & $\begin{array}{l}3.880^{* *} \\
(1.632)\end{array}$ & $\begin{array}{c}2.779 \\
(1.893)\end{array}$ \\
\hline (Private Ownership) it & $\begin{array}{c}0.397 \\
(0.606)\end{array}$ & $\begin{array}{r}-0.0142 \\
(0.711)\end{array}$ & & \\
\hline (Private Ownership) it ${ }^{*} R E R_{t}$ & $\begin{array}{l}-0.106 \\
(0.107)\end{array}$ & $\begin{array}{r}-0.0952 \\
(0.120)\end{array}$ & & \\
\hline (Private Ownership) $_{\mathrm{it}-1}{ }^{*} \mathrm{RER}_{\mathrm{t}-1}$ & $\begin{array}{c}0.176^{* *} \\
(0.0828)\end{array}$ & $\begin{array}{l}0.185^{\star \star} \\
(0.0931)\end{array}$ & & \\
\hline (Private Ownership) it-2 $^{*} R R_{t-2}$ & $\begin{array}{c}-0.102 \\
(0.0665)\end{array}$ & $\begin{array}{l}-0.150^{*} \\
(0.0785)\end{array}$ & & \\
\hline (Import dependency) it & & & $\begin{array}{l}-0.636 \\
(0.552)\end{array}$ & $\begin{array}{l}-0.818 \\
(0.628)\end{array}$ \\
\hline (Import dependency) it ${ }^{*} R E R_{t}$ & & & $\begin{array}{c}0.0730 \\
(0.0879)\end{array}$ & $\begin{array}{l}0.0360 \\
(0.100)\end{array}$ \\
\hline (Import dependency) it-1 $^{*}{ }^{*} E R_{t-1}$ & & & $\begin{array}{l}-0.0674^{*} \\
(0.0370)\end{array}$ & $\begin{array}{l}-0.0723^{*} \\
(0.0419)\end{array}$ \\
\hline (Import dependency $)_{\mathrm{it}-2}{ }^{\star} \mathrm{RER}_{\mathrm{t}-2}$ & & & $\begin{array}{c}0.0363 \\
(0.0398)\end{array}$ & $\begin{array}{c}0.0709 \\
(0.0469)\end{array}$ \\
\hline$V_{E R}$ & $\begin{array}{c}7.991 \\
(20.45)\end{array}$ & $\begin{array}{c}5.419 \\
(22.99)\end{array}$ & $\begin{array}{c}7.273 \\
(18.91)\end{array}$ & $\begin{array}{c}3.832 \\
(21.42)\end{array}$ \\
\hline $\mathrm{VER}_{\mathrm{t}-1}$ & $\begin{array}{c}-30.99 * * \\
(14.05)\end{array}$ & $\begin{array}{l}-30.44^{*} \\
(15.77)\end{array}$ & $\begin{array}{c}-29.83^{* *} \\
(12.72)\end{array}$ & $\begin{array}{l}-27.52^{*} \\
(14.41)\end{array}$ \\
\hline $\mathrm{VER}_{\mathrm{t}-2}$ & $\begin{array}{c}9.079^{* * *} \\
(2.989)\end{array}$ & $\begin{array}{l}8.990^{* * *} \\
(3.355)\end{array}$ & $\begin{array}{c}8.481^{* * *} \\
(2.666)\end{array}$ & $\begin{array}{c}8.107^{* * *} \\
(3.017)\end{array}$ \\
\hline $\mathrm{emp}_{\mathrm{it}}$ & $\begin{array}{l}-1.251 \\
(2.171)\end{array}$ & $\begin{array}{l}-1.939 \\
(2.462)\end{array}$ & $\begin{array}{l}-0.661 \\
(1.947)\end{array}$ & $\begin{array}{l}-1.587 \\
(2.230)\end{array}$ \\
\hline $\mathrm{emp}_{\mathrm{it}-1}$ & $\begin{array}{c}1.700 \\
(1.444)\end{array}$ & $\begin{array}{c}1.274 \\
(1.635)\end{array}$ & $\begin{array}{c}1.182 \\
(1.282)\end{array}$ & $\begin{array}{c}0.992 \\
(1.451)\end{array}$ \\
\hline$e^{e m p} p_{i-2}$ & $\begin{array}{c}-3.010^{* *} \\
(1.431)\end{array}$ & $\begin{array}{c}-3.432^{\star *} \\
(1.620)\end{array}$ & $\begin{array}{c}-3.675^{\star \star *} \\
(1.221)\end{array}$ & $\begin{array}{c}-3.887^{* * *} \\
(1.383)\end{array}$ \\
\hline $\mathrm{K}_{\mathrm{it}}$ & $\begin{array}{c}2.005 \\
(3.610)\end{array}$ & $\begin{array}{l}-0.461 \\
(4.239)\end{array}$ & $\begin{array}{c}4.602 \\
(3.474)\end{array}$ & $\begin{array}{c}2.269 \\
(4.029)\end{array}$ \\
\hline Constant & $\begin{array}{c}549.5^{\star * *} \\
(210.7) \\
\end{array}$ & $\begin{array}{c}656.8^{* * *} \\
(242.6) \\
\end{array}$ & $\begin{array}{c}547.0^{* * *} \\
(175.0) \\
\end{array}$ & $\begin{array}{c}599.8^{\star * *} \\
(198.9) \\
\end{array}$ \\
\hline Time-fixed Effect & Yes & Yes & Yes & Yes \\
\hline Observations & 1,000 & 1,000 & 1,000 & 1,000 \\
\hline Number of isic & 85 & 85 & 85 & 85 \\
\hline
\end{tabular}

Robust standard errors are reported in parentheses. ${ }^{* *},{ }^{* *},{ }^{*}$ denote significance at $1 \%, 5 \%$ and $10 \%$ levels respectively 
Table 6. Role of raw materials and final goods inventory levels in the exchange rate effects among industries

\begin{tabular}{|c|c|c|c|c|}
\hline \multirow{2}{*}{$\begin{array}{l}\text { Cross Variables: } \\
\text { Dep. Var.: Prod }_{\text {it }}\end{array}$} & \multicolumn{2}{|c|}{ Raw inventory } & \multicolumn{2}{|c|}{ Final inventory } \\
\hline & (1) & (2) & (3) & (4) \\
\hline Prod $_{\mathrm{it}-1}$ & $\begin{array}{l}-0.161^{*} \\
(0.0933)\end{array}$ & $\begin{array}{l}-0.0741 \\
(0.130)\end{array}$ & $\begin{array}{l}-0.147^{* *} \\
(0.0745)\end{array}$ & $\begin{array}{l}0.00627 \\
(0.118)\end{array}$ \\
\hline Prod $_{i-2}$ & & $\begin{array}{c}0.0967 \\
(0.0976)\end{array}$ & & $\begin{array}{c}0.179^{*} \\
(0.0989)\end{array}$ \\
\hline $\mathrm{RER}_{\mathrm{t}}$ & $\begin{array}{c}6.120^{* * *} \\
(2.067)\end{array}$ & $\begin{array}{l}5.973^{* * *} \\
(2.135)\end{array}$ & $\begin{array}{c}7.727^{\star * *} \\
(2.613)\end{array}$ & $\begin{array}{l}6.694^{* *} \\
(2.933)\end{array}$ \\
\hline $\mathrm{RER}_{\mathrm{t}-1}$ & $\begin{array}{l}2.553 \\
(2.215)\end{array}$ & $\begin{array}{l}2.237 \\
(2.305)\end{array}$ & $\begin{array}{c}0.839 \\
(2.370)\end{array}$ & $\begin{array}{l}0.1000 \\
(2.641)\end{array}$ \\
\hline $\mathrm{RER}_{\mathrm{t}-2}$ & $\begin{array}{c}6.621^{* * *} \\
(1.594)\end{array}$ & $\begin{array}{c}6.544^{* * *} \\
(1.644)\end{array}$ & $\begin{array}{c}6.951^{* * *} \\
(2.287)\end{array}$ & $\begin{array}{l}7.705^{* * *} \\
(2.553)\end{array}$ \\
\hline$(\text { Raw inventory })_{\text {it }}$ & $\begin{array}{l}-3.810 \\
(5.051)\end{array}$ & $\begin{array}{l}-4.431 \\
(5.242)\end{array}$ & & \\
\hline$(\text { Raw inventory) })_{i t}{ }^{*} R E R_{t}$ & $\begin{array}{l}-1.275 \\
(1.455)\end{array}$ & $\begin{array}{l}-1.357 \\
(1.502)\end{array}$ & & \\
\hline (Raw inventory) ${ }_{\mathrm{it}-1}{ }^{*} \mathrm{RER}_{\mathrm{t}-1}$ & $\begin{array}{c}0.902 \\
(1.005)\end{array}$ & $\begin{array}{c}0.852 \\
(1.037)\end{array}$ & & \\
\hline (Raw inventory) $)_{\mathrm{t}-2}{ }^{*} \mathrm{RER} \mathrm{R}_{\mathrm{t}-2}$ & $\begin{array}{c}-1.892^{* * *} \\
(0.711)\end{array}$ & $\begin{array}{l}-1.811^{\star *} \\
(0.738)\end{array}$ & & \\
\hline Final inventory $y_{i t}$ & & & $\begin{array}{l}-142.2 \\
(191.9)\end{array}$ & $\begin{array}{l}-149.5 \\
(211.3)\end{array}$ \\
\hline Final inventor $y_{i t}{ }^{*} R E R_{t}$ & & & $\begin{array}{l}-31.76 \\
(28.13)\end{array}$ & $\begin{array}{l}-19.53 \\
(31.69)\end{array}$ \\
\hline Final inventory $y_{i t-1}{ }^{*} R E R_{t-1}$ & & & $\begin{array}{l}52.38^{\star \star} \\
(20.47)\end{array}$ & $\begin{array}{l}55.92^{\star *} \\
(22.62)\end{array}$ \\
\hline Final inventory ${ }_{i t-2}{ }^{*} R E R_{t-2}$ & & & $\begin{array}{l}-20.64 \\
(22.69)\end{array}$ & $\begin{array}{l}-30.64 \\
(25.58)\end{array}$ \\
\hline $\mathrm{VER}_{\mathrm{t}}$ & $\begin{array}{c}19.33 \\
(25.20)\end{array}$ & $\begin{array}{c}18.83 \\
(25.97)\end{array}$ & $\begin{array}{c}9.311 \\
(23.34)\end{array}$ & $\begin{array}{c}12.89 \\
(25.77)\end{array}$ \\
\hline $\mathrm{VER}_{\mathrm{t}-1}$ & $\begin{array}{l}-36.95^{* *} \\
(16.29)\end{array}$ & $\begin{array}{l}-36.09 * * \\
(16.81)\end{array}$ & $\begin{array}{l}-33.95^{* *} \\
(16.28)\end{array}$ & $\begin{array}{l}-35.66^{* *} \\
(17.94)\end{array}$ \\
\hline $\mathrm{VER}_{\mathrm{t}-2}$ & $\begin{array}{l}9.483^{* * *} \\
(3.343)\end{array}$ & $\begin{array}{l}9.219^{* * *} \\
(3.456)\end{array}$ & $\begin{array}{c}9.790^{* * *} \\
(3.383)\end{array}$ & $\begin{array}{l}9.876^{* * *} \\
(3.725)\end{array}$ \\
\hline$e^{e m p} p_{i t}$ & $\begin{array}{l}-0.987 \\
(2.802)\end{array}$ & $\begin{array}{l}-1.699 \\
(2.975)\end{array}$ & $\begin{array}{l}-0.584 \\
(2.492)\end{array}$ & $\begin{array}{l}-1.053 \\
(2.756)\end{array}$ \\
\hline emp & $\begin{array}{l}4.219^{\star *} \\
(1.895)\end{array}$ & $\begin{array}{l}4.112^{\star *} \\
(1.956)\end{array}$ & $\begin{array}{c}2.446 \\
(1.631)\end{array}$ & $\begin{array}{c}2.798 \\
(1.806)\end{array}$ \\
\hline $\mathrm{emp}_{\mathrm{it}-2}$ & $\begin{array}{c}-5.037^{\star \star *} \\
(1.669)\end{array}$ & $\begin{array}{c}-5.188^{* * *} \\
(1.726)\end{array}$ & $\begin{array}{c}-3.612^{* *} \\
(1.550)\end{array}$ & $\begin{array}{c}-3.805^{\star *} \\
(1.710)\end{array}$ \\
\hline $\mathrm{K}_{\mathrm{it}}$ & $\begin{array}{c}2.995 \\
(4.988)\end{array}$ & $\begin{array}{c}1.800 \\
(5.280)\end{array}$ & $\begin{array}{c}3.301 \\
(3.900)\end{array}$ & $\begin{array}{c}2.396 \\
(4.323)\end{array}$ \\
\hline Constant & $\begin{array}{l}503.1^{* *} \\
(232.4)\end{array}$ & $\begin{array}{l}512.7^{* *} \\
(239.7)\end{array}$ & $\begin{array}{c}618.0^{* * *} \\
(208.3)\end{array}$ & $\begin{array}{c}609.7^{* * *} \\
(229.4)\end{array}$ \\
\hline Time-fixed Effect & Yes & Yes & Yes & Yes \\
\hline Observations & 1,000 & 1,000 & 1,000 & 1,000 \\
\hline Number of isic & 85 & 85 & 85 & 85 \\
\hline
\end{tabular}

Robust standard errors are reported in parentheses. ${ }^{* * *},{ }^{* *},{ }^{*}$ denote significance at $1 \%, 5 \%$ and $10 \%$ levels respectively

Another interaction variable is the labor intensity of industries (number of employees to output ratio. Number of employees to output ratio is not a perfect index to measure labor intensity, because variables like human capital, technology and productivity 
are affecting it; however that is the best index according to data constraints.). The results shown in columns 1 and 2 of table 5 . Labor intensity has no significant effect on the production growth. Columns 3 and 4 of table 5 test the effects of concentration level in various industries (which is defined as number of active firms in each industries). The results indicate this variable do not affect the relationship between real exchange rate growth and production growth across the industries.

Table 6 shows the results of estimations which consider the effects of the raw materials and final goods inventory levels and their interaction with exchange rate growth. The estimations in columns (1) and (2) the direct effect of exchange rate growth on production is positive, but the effect of interaction term which includes raw materials inventory level is negative, indicating that increase in the raw material inventory level wipe out the positive effect of exchange rate growth. It can be concluded that firms with lower levels of raw materials inventory will have stronger changes in their production responding to a similar exchange rate shock. These results are consistent with the micro founded theory that cost-minimizing firms mainly consider the raw materials costs and increasing the inventory level will make firms more resistant to exchange rate shocks.

In the second part of Table 6 , we investigate the effect of final goods inventory. According to the estimations, level of final goods amplifies the positive effect of real exchange rate growth on production growth. That means firms and industries with lower level final goods inventory are affected by exchange rate growth less than other firms.

\section{Conclusion}

This paper studies effects of exchange rate fluctuations on manufacturing production growth in Iranian industries using micro level data (4-digit ISIC codes) during 2011 to 2017. We found that the effect of real exchange rate growth on quarterly production growth is depend on currency crisis situation. It means in the non-crisis periods, a real depreciation has positive impact that remain significant until two quarter later. But, the positive effect of the depreciation is eliminated under a currency crisis. Moreover, Consistent to theoretical predictions, increasing the exchange rate volatility and uncertainty decrease the production growth rate. The positive impact of depreciation in non-crisis periods and the negative effects of exchange rate volatility in all period are robust to varying the specification.

The main contribution of this paper is checking the heterogeneity in exchange rate effects on production growth across industries. We examine the role of industries characteristics in the relationship between the exchange rate growth and production growth in the industry level. To do so, the main specification model is extended by adding the pivotal characteristics of industries and their interactions with exchange rate growth. According to the results, in addition to the degree of export orientation and import dependency which theoretically and empirically have strong effects in the relationship between the exchange rate and production in industries, our findings confirm that accessing to preferential exchange rate, and level of raw material inventory and final good inventory influence exchange rate and production relationship among the industries. In other words, export orientation, access to the preferential rate and higher level of raw 
material inventory amplify the positive effect of the real depreciation while import dependency and higher level of final goods inventory fade the effect and turn in to negative in some industries (which are over the thresholds). In addition, ownership structure (private or public), the concertation measure, and labor intensity do not have significant effect on the production growth among the industries.

Generally, according to the results, heterogeneity of exchange rate effects in industries implies the side effects of monetary and exchange rate policy on production growth vary across the industries. Moreover, concurrency of raising volatility and changing the level of exchange rate, especially in countries with weak financial development is a common object. Therefore, in order to avoid misinterpreting, the negative effect of exchange rate volatility should be separated from effects of change in the exchange rate level.

\section{References}

Agenor, P. R. (1991). Output, devaluation and the real exchange rate in developing countries. Review of World Economics, 127(1), 18-41.

Aghion, P., Bacchetta, P., Ranciere, R., and Rogoff, K. (2009). Exchange rate volatility and productivity growth: The role of financial development. Journal of monetary economics, 56(4), 494-513.

Aliyu, S. U. R. (2009). Impact of Oil Price Shock and Exchange Rate Volatility on Economic Growth in Nigeria: An Empirical Investigation (No. 16319). University Library of Munich, Germany.

Balogun, E. D. (2007). Exchange rate policy and Export performance of WAMZ countries. MPRA parer,6233:23-44

Balassa, B. (1978). Exports and economic growth: further evidence. Journal of development Economics, 5(2), 181-189.

Bruno, M. (1979). Stabilization and Stagflation in a Semi-Industrialized Economy," in R. Dornbusch and J. Frankel, eds. International Economic Policy, Johns Hopkins University Press, Baltimore, MD.

Burgess, S. M., and Knetter, M. M. (1998). An international comparison of employment adjustment to exchange rate fluctuations. Review of International Economics, 6(1), 151-163.

Choi, K. (1983). Theories of comparative economic growth. lowa State Press.

Choi, B. Y., and Pyun, J. H. (2018). Does real exchange rate depreciation increase productivity? Analysis using Korean firm-level data. The World Economy, 41(2), 604-633.

Dornbusch, R. (1988), Open Economy Macroeconomics. 2nd edition. New York.

Dornbusch, R., Werner, A., Calvo, G., and Fischer, S. (1994). Mexico: stabilization, reform, and no growth. Brookings papers on economic activity, 1994(1), 253-315.

Dhasmana, A. (2015). Transmission of real exchange rate changes to the manufacturing sector: The role of financial access. International Economics, 143, 48-69.

Edwards, S. (1989). Real exchange rates, devaluation, and adjustment: exchange rate policy in developing countries (pp. 16-25). Cambridge, MA: MIT press.

Eichengreen, B. (2007). The real exchange rate and economic growth. Social and Economic Studies, 56(4), 7-20.

Eichengreen, B., and Gupta, P. (2012). The Real Exchange Rate and Export Growth: Are Services Different? (No. 43358). University Library of Munich, Germany.

Galindo, A., Izquierdo, A., and Montero, J. M. (2007). Real exchange rates, dollarization and

Guitian, M. (1976). The effects of changes in the exchange rate on output, prices and the balance of payments. Journal of International Economics, 6(1), 65-74. 
Gopinath, G., and Itskhoki, O. (2009). "Frequency of Price Adjustment and Pass-through", Quarterly Journal of Economics, 125(2), 675-727.

Kamin, S. B. (1988). Devaluation, external balance, and macroeconomic performance: a look at the numbers. International Finance Section, Department of Economics, Princeton University.

Kamin, S. B., and Rogers, J. H. (2000). Output and the real exchange rate in developing countries: an application to Mexico. Journal of development economics, 61(1), 85-109.

Kochen, F., and Samano, D. (2016) "Price Setting and Exchange Rate Pass-Through in the Mexican Economy”. Bank of Mexico Working Papers, No.13.

Kindleberger, C. P. (1962). Foreign trade and the national economy (No. HF1007 K52).

Krueger, Anne (1998), "Why Trade Liberalization is Good for Growth,"Economic Journal 108, 15131522.

Krugman, P., and Taylor, L. (1978). Contractionary effects of devaluation. journal of International Economics, 8(3), 445-456.

Ram, R. (1985). Exports and economic growth: Some additional evidence. Economic Development and Cultural Change, 33(2), 415-425.

Saadiah, M and Kamaruzaman, J (2008), Exchange Rate and Export Growth in Aian Economies. Journal of Asian Social Science, 11(4): 30-35.

Schnabl, G. (2008). Exchange Rate Volatility and Growth in Small Open Economies at the EMU Periphery. Economic Systems, 32(1), 70-91.

Stanèík, J. (2007). Determinants of Exchange-Rate Volatility: The Case of the New EU Members. Czech Journal of Economics and Finance (Finance a uver), 57(9-10), 414-432.

Lu, X., and Dai, G. (2005). The influence of fluctuation of real RMB exchange rate to Chinese import and export: 1994-2003. Economic Research Journal, 5, 31-39.

Van Wijnbergen, S. (1986). Exchange Rate Management and Stabilization Policies in Developing countries. Journal of Developme 